\title{
土地所有関係の変遷から見る在日コリアン集住地区の形成過程に関する研究 \\ THE MAKING OF A KOREAN COMMUNITY AT HIGASHI-KUJO OF KYOTO: FROM VIEWPOINT OF RELATION BETWEEN A LAND READJUSTMENT PROJECT AND LANDOWNERSHIP BY THE KOREAN
}

\author{
韓 勝 旭*, 布野修司**, \ムボン*** \\ Seoung Wook HAN, Shuji FUNO and Bon LIM
}

\begin{abstract}
Our research intends to analyze the making process of Korean communities in Japan. Especially, this paper aims to find characters of the transitional process of landownership by the Korean in Higashi-Kujo area of Kyoto City. The all the factors, it was the Land Readjustment project by a public organization which most attracted the Korean to come to settle in this area. At the result of this study, we founded that Land Readjustment Project practiced in there accelerated the gathering and subsequently settling process of Korean people in the quarter. The approval of article 13 in the former City Planning Law enforced Land Readjustment Project that provided infrastructure to the quarter, hence caused an increase in land price. For the financial benefit from the development, previously stayed landlords sold their lands to any newcomers. So that, Korean people living in Japan could take an opportunity for obtaining landownership with ease. The process of acquisition of landownership by the Korean people from related authorities such as the Ministry of Finance and Kyoto City via public organization has very distinctive features.
\end{abstract}

Keywords: Korean Community, Landownership, Land Readjustment コリアン集住地区、土地所有、区画整理

\section{1. 研究の目的と背景}

本研究は、日本国内に散在する在日コリアン集住地区の都市構造 上の問題点を整理し、その改善に向けた諸方策のあり方を提示する ことを指向している。そこで本稿では、京都市東九条地区を対象と して、その形成過程の特質を、特に土地所有関係に着目して明らか にすることを目的としている。

韓・日併合が行われた 1910 年には 2,527 人であった在日コリアン の人口は、1945年には2, 365, 263人となっていた。渡日初期には、 求職・出稼ぎや強制徴用などの理由で来日し、終戦から朝鮮戦争の 勃発する前までに約 80 万人が州国し、残り１50万人以上が日本に定 住した。初期に渡日した在日コリアン1世の大半は、職場に近い住 工混合地区に居住してきたが、現在、そうした地区は、産業構造が 変化することによって衰退するなど、それぞれ問題を抱えつつある 1 。

在日コリアン集住地区の問題は、歴史的かつ世界的にみても、大 都市におけるマイノリティ・コミュニティの発生という普遍的現象 の一つとしてとらえることができる。そのような点から、本研究 は、1980年代以降、日本に流入してきた多くのアジア人たち（いわ ゆるニューカマーと呼ばれる人々）が形成しつつある集住地区の今 後のあり方を考える上での参考資料となる得りものと考える。

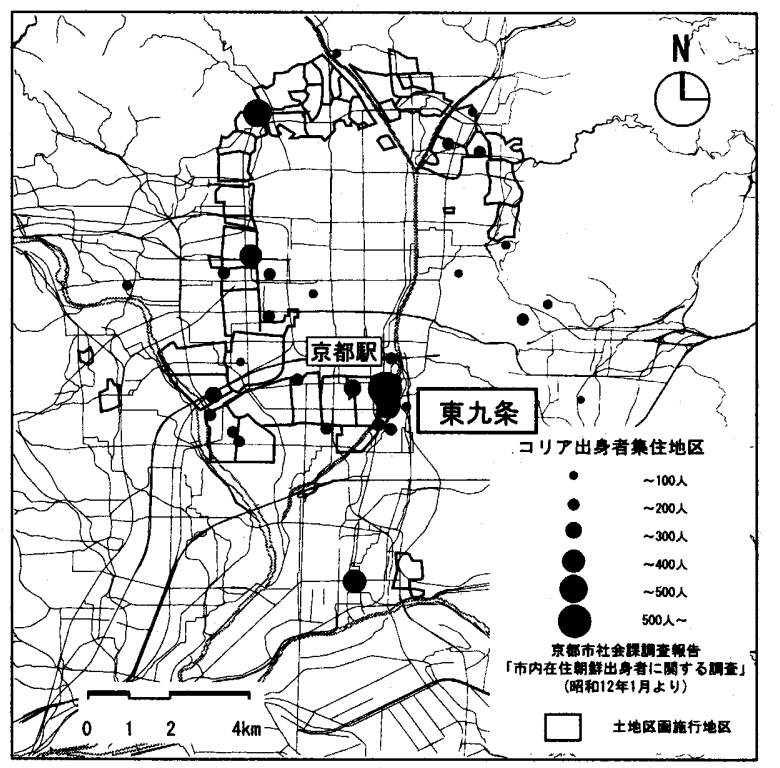

図1. 土地区画整理事莱施行地区とコリアン集住地区 (出典: 京都市社会锞娚查辄告害より作成)

在日コリアンに関する研究は、社会学、民族学、教育学を含め多方 面で行われている。主要な論文は末尾に挙げる通りである。なかで
* 京都大学大学院工学研究科 博士後期課程

** 滋賀県立大学大学院環境科学研究科 教授 · 工博

*** 立命館大学産業社会学部 教授・工博
Graduate Student, Graduate School of Eng., Kyoto Univ., M. Eng.

Prof., Graduate School of Environmental Planning, The University of Shiga Prefecture, Dr. Eng.

Prof., College of Social Sciences, Ritsumeikan Univ., Dr. Eng. 
も、池上地区、桜本地区、戸手地区 以上川䗁市）、寿地区（横浜市）を分 析対象として在日コリアンの渡日過程 と終戦後日本に残留したコリアンの生

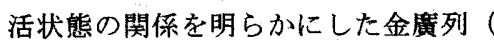
1997）の研究は特筆すべきである。東 九条地区に関する研究としては、吉田 友彦らによる業績がある²。これは、 不法占拠地区を 10 年閒の 2 時点で居住 者構造の変遷に関する実態調査を実施 し、その成果を、公営住宅建設を中心 とした住環境整備に反映させたもので

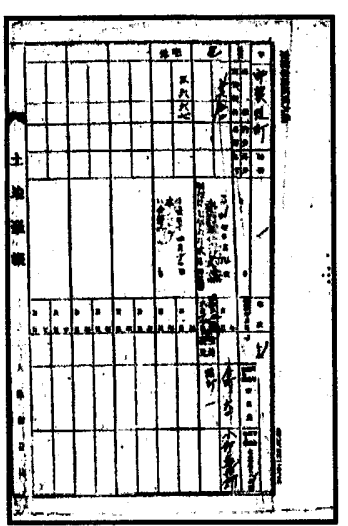

图2. 旧土地台帳 ある。

本稿では、分析対象となる東九条地区において、形成過程の特質 を土地所有関係に着目している。

\section{2. 研究方法}

上述のように、本稿では、土地区画整理事業の換地処分が終了し た直後から11年間の東九条地区のコリアンの土地所有関保の変遷を 分析する。地区の住宅密集の推移、土地所有関係、コミュニティ活 動の三点に焦点を当て、図面作成、文献調查、開き取り調查を実施 した。

（1）住宅密集の推移については、「都市計画基本図」（1929、 1936、1953、1962、1975、1996、2002）、「地籍図」、「住宅地 図」（1951 2001）、「航空写真」（1946、1961、1972、1987、 1998）をデジタルデータ化した。特に、土地区画整理事業計画図（ 1936、縮尺1/2100）は、土地の形態とその上に建てられている住宅 のプランも描かれている貴重な資料であり、本稿の主要な図面であ るコリアンの土地所有地分布図（図 7）を復元する作業に用いられ た。また、2003年5月から2004年10月までの間に計 7 回現地調査を 実施し、東九条地区の施設分布、建築類型などをべースマップにプ ロットする作業を行った。

(2) 土地所有関倸については、土地所有変化及び分筆・合筆が一番 激しい時期であった換地処分（1951年）後11年間を中心として、「 旧土地台帳」 ${ }^{3}$ の分析を行った。具体的には、東九条地区の651筆地
に関して所有者の変化、そのパターン、分筆・合筆とそれに伴う土 地面積の変化、所有変化の時期などをデータ化した。特に、土地を 購入したコリアンの前住所を分析して、東九条地区におけるコリア ンの集住パターンを明らかにした。

（3）聞き取り調查は、コリアン関連団体（民団・総連） ${ }^{4}$ 、東九 条まちづくりサポートセンター、N P O 法人京都コリアン生活セン ター「エルファ」に対して行った。

コリアン関連団体からは、コリアン住民の団体所属人数の変動、 帰化したコリアンを含む居住分布状況などのデータを提供してもら った。東九条まちづくりサポートセンターは、1970年代後半から東 九条地区の住民運動に梁くかかわっており、現在、京都市から委託 され、東松ノ木町に建てられた公営住宅の管理業務を行っている。

N P O法人京都コリアン生活センター「エルファ」は、コリアン の生活支援と共に、デイケアセンター、保育施設、障害者作業所な どを運営する地域密着型の団体である。そこでのデイケアセンター 利用者と職人を対象とした閶き取り調查を実施した。

\section{3. 地区の現況}

京都市南区は住工混合地区が多く、広域的な交通網が集積する地 域である。職住が共存する古い市街地、新興住宅地、工場集積地の ほか、農地も比較的に多く散在しており、大規模な開発事業が進め られている ${ }^{5}$ 。特に東九条は、戦後まもなくまで染色工場や鉄工所 などが集中していた工業地域であった。

京都市における最大のコリアン集住地区である東九条は、京都駅 から東南側に位置している(図 1)。その中に山王学区（公称町数 13町）と陶化学区 (公称町数 11 町) を含む。本稿では対象地を山王 学区の 4 力町 (東. 南岩本町、北・南河原町) と陶化学区つ 4 力町（ 河西町、宇賀辺町、北・南松ノ木町) に絞った(総面積は $0.292 \mathrm{~km}$ で ある)。東九条地区を囲んでいる重要幹線道路は、北側には八条通 が南側には十条通があり、東側には河原町通が走っている。東九条 地区の用途地域指定状況は、九条通を中心として北側は住居地域、 南側は準工業地域に分けられる（図 3、4）。北側の河原町通及び 九条通沿道の道路境界から $25 \mathrm{~m} の$ 幅のエリアでは、第2種居住地域の 指定がされておう、それ以外のエリアは、第 1 種住居地域に指定さ れている。南側の河原町通及び九条通沿道の道路境界から $25 \mathrm{~m}$ 幅

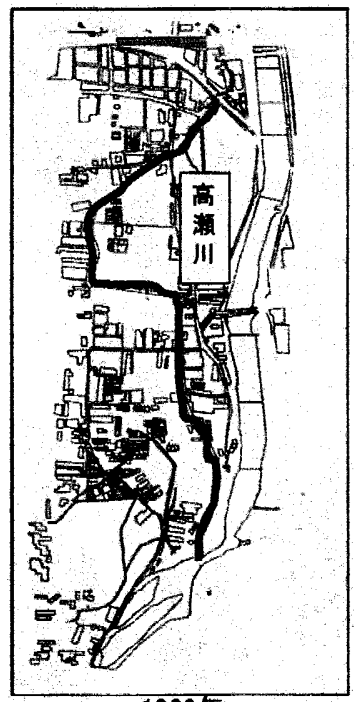

1929年

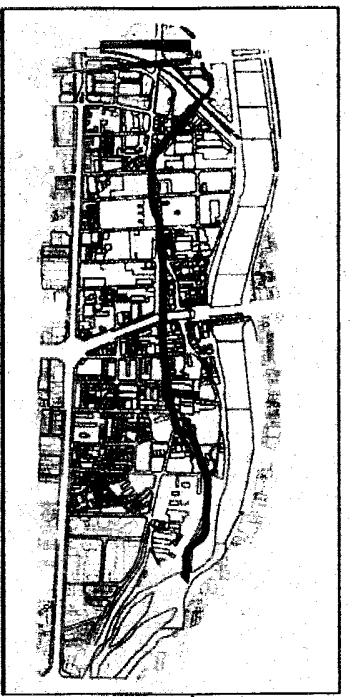

1953年

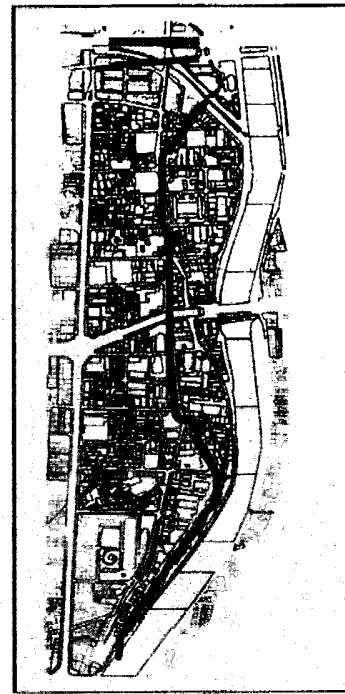

1972年

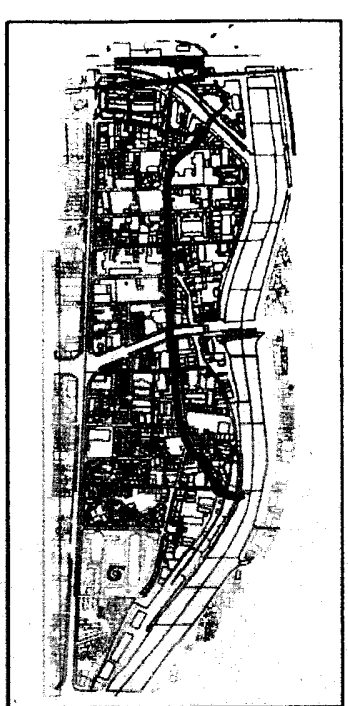

2004年

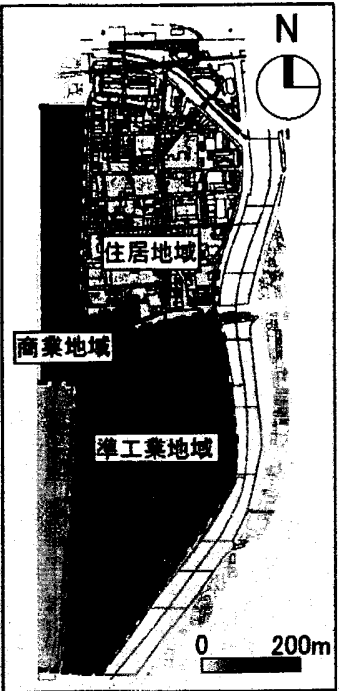

用途分布

图3. 東九条地区の用途分布と高瀬川の変 (京都市の都市咶画基本国により作成) 


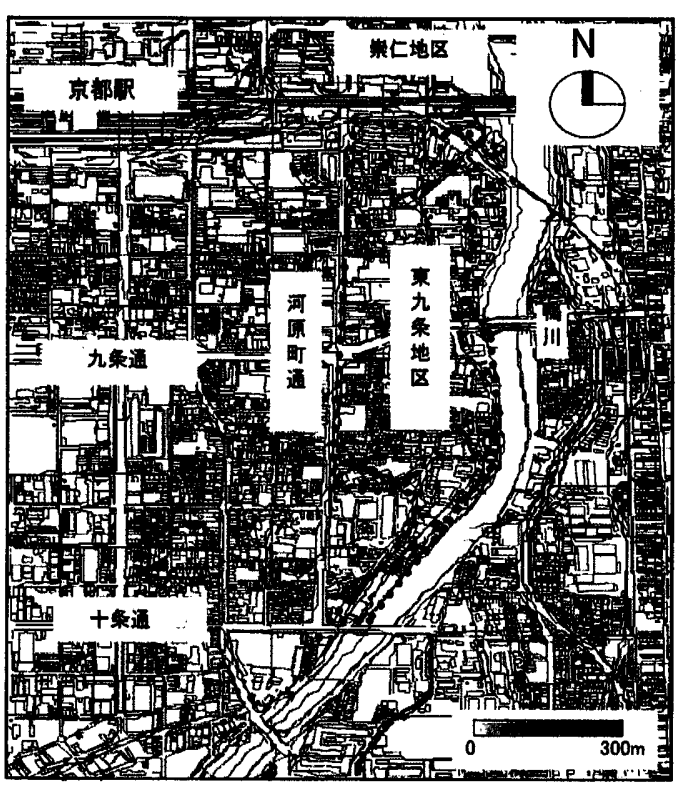

图4. 東九条地区の位置

のエリアは、容積率 $300 \%$ 、高度制限 $20 \mathrm{~m}$ 、建蔽率 $60 \%$ の第 4 種準工 業地域であり、他のエリアは、第3種準工業地域である。また河原 町通と九条通が交差寸るエリアは、商業地域に指定され、容積率 $600 \%$ 、高度制限 $31 \mathrm{~m}$ 、建蔽率 $80 \%$ である。東九条地区には、都市計 画道路として河原町通、九条通、十条通があり、河原町通の塩小路 〜八条通間が拉幅整備を実施中である（図 3 ）。「平成 12 年国勢調 査」によると、東九条地区の人口構成は、4813人、2001世帯であ る。南松ノ木町が全体の $32 \%$ を占め、1553人と最も多く、次いで宇 賀辺町の803人、北松ノ木町の 659 人、東岩本町の610人である。全 地区の人口はピーク時 1965 年の約 $1 / 3$ 程度まで減少した。年制構成 は、2000年現在、15歳未满が $9.3 \% 、 15$ 歳 24 歳が $55.3 \% 、 65$ 歳以 上が $35.4 \%$ となっている。65歳以上の人口が $14.7 \%$ でる京都市全 体と比べて、高龄化が進んでいる地区と言える。東九条地区に住ん でいる外国籍市民は、1084人であり、住民の $22.3 \%$ 占めている。 そのほとんどが韓国及び朝鮮国籍を有している。これは、京都市全 体の $2.9 \%$ をきく上回っている。

\section{4. 地区の形成}

\section{4-1. 東九条村の変遷}

明治初期の東九条村には青权ぎ畑がひろがり、その中で農家が点 在している程度であったが、次第に人口が集中し始める。(1)1877年 に京都一神戸間に鉄道が開通したこと、(2)1880年以後、東海道線敷 設のために北に隣接する崇仁地区から立ち退かされた住民が流入し たこと、(3)西九条地域で部落差別が行われ、部落民の一部が移住 してきたことがその理由である゙。1916（大正5）年に実施された 「東九条村の職業別現住戸口調心゙」には、「農業人口 1,306 人、以 下、工業 363 人、商業 1,761 人、その他 2,910 人、無業・不詳 53 人、 計 6,393 人である。これは1907（明治40）年の人口と比べて 2.3 倍増 加している。」と書かれている。急速な都市化の中で、東九条村は 1918 （大正7）年に京都市に編入されるが、この頃より居住問題が 表面化し始める。第一世界大戦の勃発は大戦景気をもたらし、纎維 産業を中心として工業生産額が飛躍的に伸びたが、都市部には大量 の工場労㗢者が流入し、居住問題が引き起こされるのである。京都
ではその市街中心部に流入者を受け入れる余裕がなかったため、都 市基盤が未整備の市周辺部に吸収されていくことになった。1925（ 大正14）年の「失業統計調查」には、「東九条地区を含む陶化地区 に勤めいている日㕍労働者は多い」と書いている。戦前期における 人口集中は東九条北部にある四力町の一部に限定された。戦後にな ると、(1)北隣の崇仁地区で戦時中、防火帯(須原通)をつくるために 强制退去が行われたことにより当該住民が移転来住したこと、(2)ヤ ミ市が東海道線の南側にできたことにより生活の利便さが高まった こと、を主な理由として人口が増加した ${ }^{7}$ 。

\section{4-2.コリアンの集住過程}

京都市には1910年代から既にコリアンが居住しており、韓（朝 鮮）半島からの渡航制限が無くなった1922（大正11）年ごろから 増加の㑯向を示している。新市街地として急激な膨張をとげ、労 働力を吸収した東九条地区は、とりわけ崇仁地区（東九条地区の 北部）の生活圈内に含まれる岩本町北部に移住者吕增加した ${ }^{8}$ 。更 に、1925（大正14）年に京都協助会館が建設されることによって、 その傾向が促進された ${ }^{9}$ 。1928（昭和3）年に発行された「京都市 教育部社会橦季報第5号」には、岩本町に居住しているコリアンに ついて「コリアンの場合、収入の一般的低位とそれに基づく生活様 式全般の低位化はより高度なる生活圈の中に生存することが不可能 であり、低位生活を維持せしめる安易の地を求め、不良住宅地区で ある岩本町に集住した」と述べている。南河原町と松ノ木町北部に は、当時、九条大橋架橋工事に従事するコリアン労働者を受け入れ る長屋があった。当時のコリアンの住居について、「市内在住朝鮮 出身者に関する調查」（1937年）には、「木造平屋で建築年路 2 30 年、相当荒廃しており、1户の大きさは大体 4 畳半及び3畳の 2 間で あるが、数世帯群居せるもの多く、その世帯数 $127 、 人$ 員 564 人であ る。(中略)職業としては日雇、土工、屑倍、工場雑役などである。 (後略)」と記録されている。南河原町と松/木町に限ってコリアン の移住および集住地区の形成は、架橋工事を含む九条通の搪幅工事 が始まった1933（昭和8）年前後から本格的に始まったと推定され る。更に1938（昭和8）年11月に発行された「京都府協和会要覧」 では、北河原町、宇賀辺町にもコリアンが居住していたと書かれて
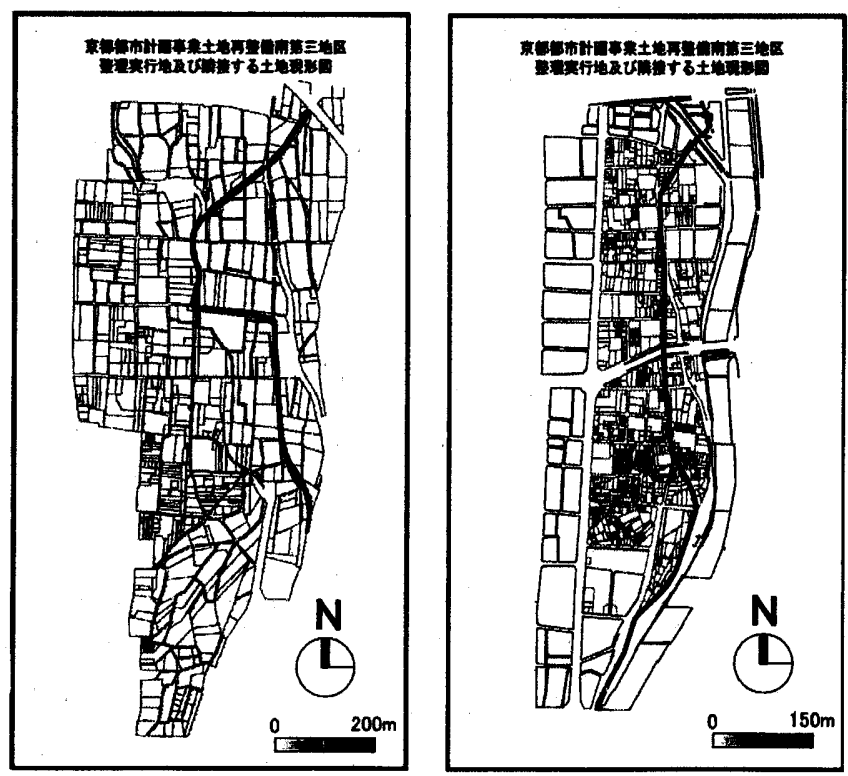

图5. 京都都市計画事莱土地再整傅南第三地区 整理实行前の土地現形图因と整理実行後の土地現形図因 (出典:土地区面整理事亲部画图之地籍图により作成) 
表1. 東九条地区におけるコリアンに関する土地所有变化のパターン

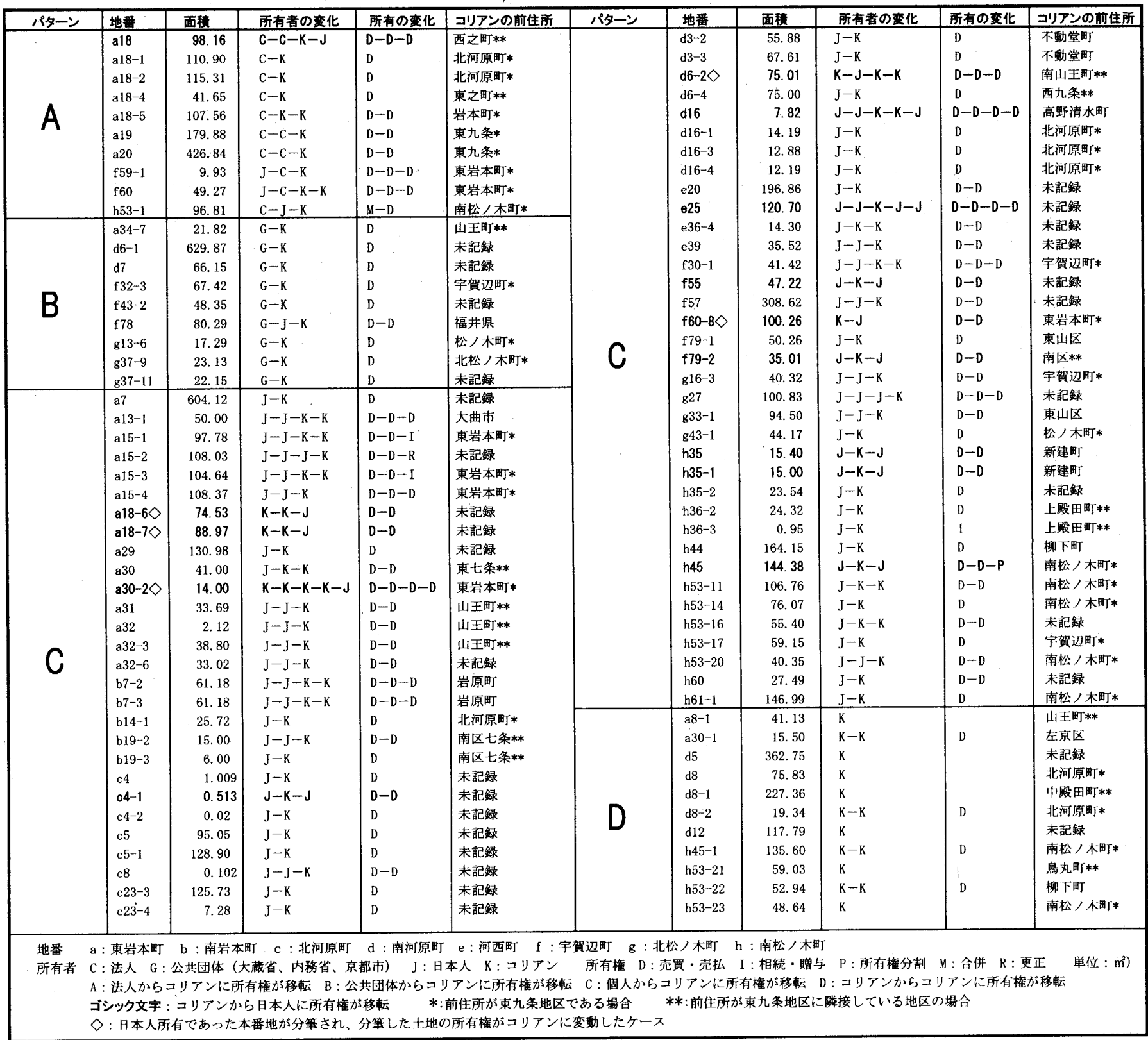

いる。

東九条地区には仕事と居住地を求める人々が集まってきた。地区 の居住者は「土地の購入はもちろん家さえ借りられなかったコリ アンと日本人は、堤防の上にバラックを建ってた。このような住宅 は、廃材などを利用してわずか 12 日で作ったものであり、1人あ たりの畳数は一畳内外の劣覀な住宅もあった。また便所は共同で使 用し、広さ、設備、構造ともに極めて低質なものであった」と述べ ている。バラックが形成された高瀬川と鴨川に挟まれている堤防の 周辺には、廃品回収業の倉庫及び作業所が乱立した。1951年に勃発 した朝鮮戦争がもたらした好景気は、当時東九条地区にある廃品回 収業を活性化させる大きな要因となった ${ }^{10}$ 。1955（昭和30）年か らは「改良住宅」の崇仁地区（図 4) 八の建設によって、日本国籍 を持たない人は追い出されて東九条地区へ流入することになった 1 。

\section{5.土地所有の変化}

\section{5-1．京都市における土地区画整理事羓}

表2. 土地所有変化のパターンとコリアンの前住所(临位: $\mathrm{m}, \mathrm{n}$ : 筆地数

\begin{tabular}{|c|c|c|c|c|c|c|}
\hline & $* / 33$ & $* * / 17$ & 未轭録/30 & 他地城/14 & 合竍 $/ 94$ & 粠成比 \\
\hline$A / 10$ & $1096.5 / 8$ & $139.81 / 2$ & 0 & 0 & 1236.31 & $15.67 \%$ \\
\hline$B / 9$ & $107.84 / 3$ & $21.82 / 1$ & $766.52 / 4$ & $80.29 / 1$ & 976.47 & $12.40 \%$ \\
\hline $\mathrm{C} / 64$ & $1189.64 / 18$ & $346.9 / 11$ & $2328.734 / 24$ & $642.98 / 11$ & 4508. 254 & $57.23 \%$ \\
\hline$D / 11$ & $279.41 / 4$ & $327.52 / 3$ & $480.54 / 2$ & $68.44 / 2$ & 1155.91 & $14.70 \%$ \\
\hline 合社 $/ 94$ & 2673.39 & 836.05 & 3575.794 & 791.71 & 7876. 944 & $100.00 \%$ \\
\hline
\end{tabular}

表3. 町別コリアン所有土地の面樌とコリアンの前住所(単位: $\mathrm{m}^{*}, / \mathrm{n}$ : 篭地数)

\begin{tabular}{|c|c|c|c|c|c|c|}
\hline & $* / 33$ & $* * / 17$ & 未㓤粶/30 & 他地城/14 & 合社/94 & 構成比 \\
\hline$a / 25$ & $1265.28 / 9$ & $318.37 / 8$ & $1039.65 / 6$ & $65.5 / 2$ & 2688.8 & $34.13 \%$ \\
\hline$b / 5$ & $25.72 / 1$ & $21 / 2$ & 0 & $122.36 / 2$ & 169.08 & 2. $14 \%$ \\
\hline $\mathrm{c} / 8$ & 0 & 0 & $358.604 / 8$ & 0 & 358.604 & $4.55 \%$ \\
\hline$d / 15$ & $134.43 / 5$ & $377.37 / 3$ & $1176.56 / 4$ & $131.31 / 3$ & 1819.67 & $23.10 \%$ \\
\hline$e / 4$ & 0 & 0 & $367.38 / 4$ & 0 & 367.38 & $4.66 \%$ \\
\hline$f / 11$ & $268.3 / 5$ & $35.01 / 1$ & $404.19 / 3$ & $130.55 / 2$ & 838.05 & $10.63 \%$ \\
\hline $\mathrm{g} / 7$ & $124.91 / 4$ & 0 & $122.98 / 2$ & $94.5 / 1$ & 342. 39 & 4. $34 \%$ \\
\hline$h / 19$ & $854.75 / 9$ & $84.3 / 3$ & 106. $43 / 3$ & $247.49 / 4$ & 1292.97 & $16.45 \%$ \\
\hline 合彭/94 & 2673.39 & 836.05 & 3575.794 & 791.71 & 7876.944 & $100.00 \%$ \\
\hline
\end{tabular}

京都市では、1907（明治40）年以後、三道路拡築・軌道敷設、上 下水道建設、第二疏水建設といった、いわゆる三大事業と呼ばれ 
た市街地整備事業が推進された。都市基盤整備事業が完了した以降 は、都市周辺部を整備する必要性が高まっていた。

京都市における土地区画整理区が、1928（昭和3）年7月に認可を 得た時点で、総面積は約 $140,500,000 \mathrm{~m}^{2}$ であった。東九条地区が属 している南第三地区は、東面方向を東洞院通と鴨川に挟まれ、北側 は八条通を経て東七条に接し、南側は十条通によって区画される地 区であり、官有水路、道路を含む総面積は $558,384 \mathrm{~m}^{2}$ である。南第 三地区では、1936（昭和11）年5月22日から京都市代執行による土 地区画整理事業が始まる。

北・南岩本児童公園はこの時に設けられた ${ }^{12}$ 。現在の幅員 $6 \mathrm{~m}$ 以 内の道路はほとんどこの時にできたものであり、逆にその以後に建 設された道路はほとんどが $6 \mathrm{~m}$ 未満 $(3 \mathrm{~m}$ 前後) である。戦後の人口急 增期に急増した木造のアパート・住宅を無計画に建てたためであ る。幅員 $1.5 \mathrm{~m} \sim 3 \mathrm{~m}$ の細街路や袋小路は最初から存在していたのでは なく、住宅を建てた残りの土地として現れた。この結果、現在のよ うな比較的大きな街区の中に網目のように細街路、袋小路が巡る街 路構造が形成された（図 5 の右）。

地域内を還流する高瀬川 ${ }^{13}$ について、鉄笳コンクリートで護岸 工事が行われ、河床には、既存の流域間に3简芹の落差が設置されれ て、川の勾配を調節し、河川水を灌溉用水としても利用する計画が なされた（図 3、5）。灌溉水路は、北河原町補助街路第86号線よ り水路が分かれ、須原通の西側に灌溉用水を提供しており、松ノ木 町においては補助街路第7号線の北端から取水するように設計がな された。

\section{5-2.コリアンの土地所有形態}

南第三地区は土地区画整理事業が終了した後、1951（昭和26）年 5月に換地処分が行われた。換地処分後の土地の所有権が奇蹟記载 されている旧土地台帳及び登記簿を分析した結果によると、東九条 地区における土地所有の変化が一番激しい時期は換地処分の直後か ら11年間である。
土地区画整理事業をきかっ けとして街区とインフラスト ラクチャーの整備が行われ地 価が上昇した。換地処分が終 わった1951（昭和26）年から 地主達は、上昇した地価から 開発利益を回収するために所 有した土地を売買し始めた。 開発によって生じた利益は、 公共団体による強制的な市街 地の開発方式において地主一 の補償を行う役割を果たし た。

東九条地区のコリアンは、 活発に行っていた土地の引取 りを通じて、法人（関西電 力、京都電気）、公共団体（ 大藏省、内務省、京都市) 、 既存の地主から土地の所有権 を取得した。公共団体が保有

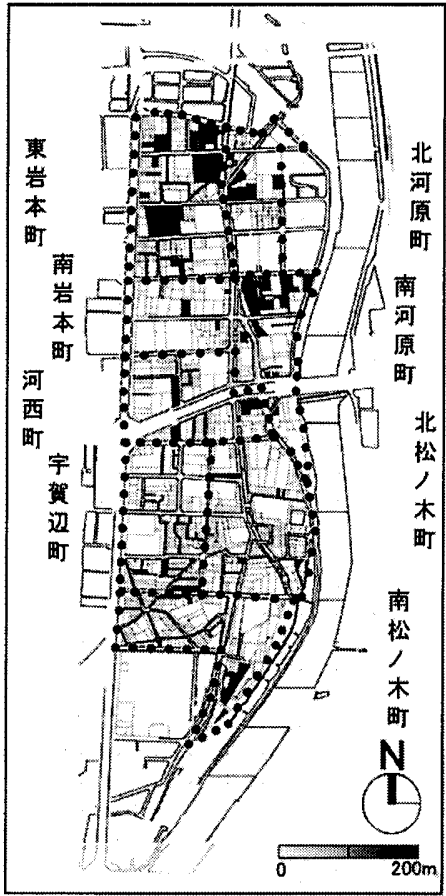

图6. コリアン所有土地の分布
した保留地 ${ }^{14}$ の一部をコリアンに直売したケースがあり、家を借 りることさえ厳しかった当時の事情から考えると、コリアンが国や 法人から土地を購入することができた意味は非常に大きい。

コリアンに関する土地所有のパターン(表 1 )によると、コリアン が所有した土地は、94筆地、総面積7876.944 $\mathrm{m}^{2}$ である(図 6)。日 本人（個人）からコリアンに所有権が移転したCパターンは、64箻 地、総面積が $4508.254 \mathrm{~m}^{2}$ で、コリアンが所有した土地の57. $24 \%$ を占 めている（表 2）。コリアンが所有した土地の平均面積は $83.8 \mathrm{~m}^{2}$ で、70.44 m²゙あるCバターンを除く3つのバターンの場合、Aパター ンは123. $63 \mathrm{~m}^{2} 、 B ハ ゚ タ ー ン は 108.5 ~ \mathrm{~m}^{2} 、 \mathrm{D} ハ ゚ タ ー ン は 105.08 \mathrm{~m}^{2} て ゙$ 全土

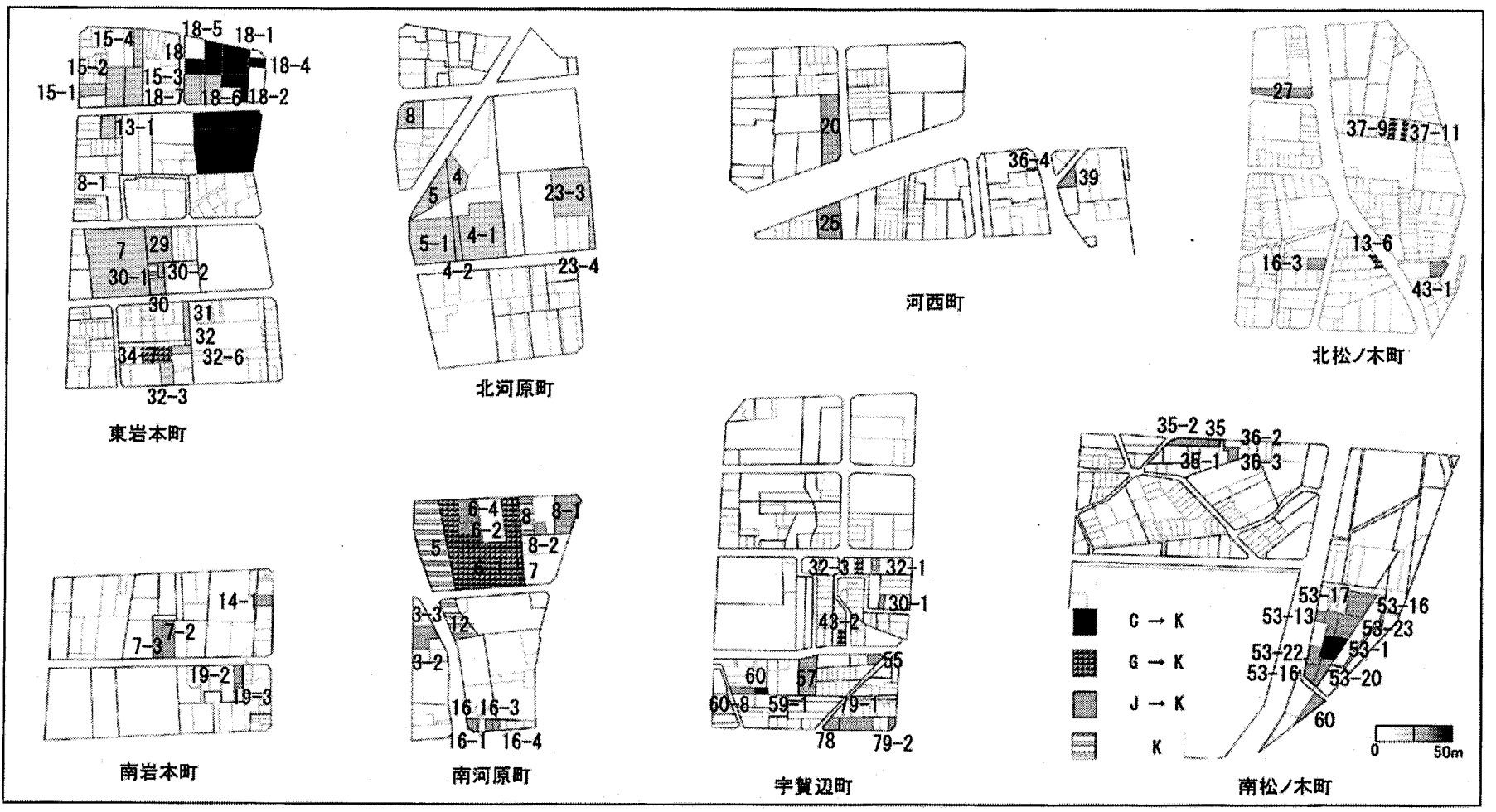

图7. 各町コリアン所有土地分布図 
地の平均面積を上回る。法人からコリアンに所有権が移転したAパ ターンと公共団体からコリアンに所有権が移転したBパターンの場 合は、法人の倉庫や公共団体が保留地として保有した土地であるた め、その規模が大きいのは珍しいことではない。反面、コリアンが 換地処分直後から大規模の土地を所有したことから、コリアンの中 で大規模の土地を購入できる階層が現れたといえる。さらに土地を 購入したコリアンが土地の所有権を日本人に売買したケースも 14 筆 地、総面積 $836.973 \mathrm{~m}^{2}$ で、コリアンが所有した全土地の $10.62 \%$ 占 めている。コリアンから日本人に所有権が移られた14ケース中で 13ケースは土地の分筆と共に所有権が売買された。残りh45の場合 は、所有の変化が所有権の分割によって行われた。その理由は、 1954年5月に土地の所有権を取得するとき、コリアンと日本人が共 同名義で登記したが、1957年12月に土地を分筆し、h45は日本人に 所有権を移転させ、分筆された $\mathrm{h} 45-1$ はコリアン単独所有となった。

土地を購入したコリアン及び日本人の場合、土地を取得する前の 住所が旧土地台帳に書かれている。表2は、前住所と土地所有変化 のパターンと関連をつけたもので、分析をした結果、次の事実が明 らかになった。所有者の前住所が東九条地区である34筆地、総面積 $2795.75 \mathrm{~m}^{2}$ と、前住所が東九条地区に隣接している地域である 16 筆 地、総面積 $836.05 \mathrm{~m}^{2}$ を合わせ、コリアンが所有した全土地の約 $46 \%$ を東九条地区及びその周辺に居住している人々が購入した。前住所 が末記録である29筆地、総面積 $3547.774 \mathrm{~m}^{2}$ を除いても、前住所が他 地域であるケースは15筆地、総面積702. $37 \mathrm{~m}^{2}$ に過ぎない。すなわ ち、東九条地区においてコリアンが所有した土地の約 $8 \%$ が他地域 から流入してきた人々に売買された。

コリアンに関する土地所有の変化と特徴を各町別に考察すると次 のようである。

東岩本町の131筆地においてコリアンの所有であった土地は、 24筆地、面積2688. $8 \mathrm{~m}^{2}$ である。コリアンにかかわる土地所有の変化 としては、日本人（個人）加 12 件、法人から7件、公共団体（大 蔵省）から1件の所有権を取得したケースがある。また、換地処分 後、大規模の土地を購入したコリアンが土地の分筆を行い、細分化 された土地の一部分を日本人に売買したケースも4件ある。東岩本 町は、コリアンの所有地が東九条地区の中で最も多い町である。そ の理由は、(1)JR線複線化工事など大規模の土木工事に日雇い労働者 として勤めたコリアンの多数が職場から近い所に居住したこと、 (2)法人が保有した市電の車庫が市電路線の整備に従って売却される ようになったこと、が举げられる。コリアン労働者が東岩本町に移 住した時、人夫部屋及び飯場に住み始めた。飯場とは土建工事現場 の周辺に労働者の寝食を有料で提供するもので、従来から日本人建 設労働者の臨時宿舎として利用されていたが、コリアンの建設労働 者の増加によって、コリアンが運営するコリアン労働者専用の飯場 が東岩本町に登場した。コリアンの中には借間・借家に成功する人 が現れ、彼らが換地処分後大規模の土地を購入した。また、法人 から取得した土地は、総面積1080. $3 \mathrm{~m}^{2}$ に至る大規模の敷地であり、 a18の場合は 1953 年 3 月にコリアンが土地の所有権の取得と共に分筆 を行い、細分化された土地をコリアンと日本人に再売買した。

南岩本町の 30 筆地においてコリアンが所有した土地は、5筆地、 総面積169. $88 \mathrm{~m}^{2}$ であり、全てが日本人から所有権を取得したケース である。東岩本町よりコリアンが所有した土地が少ない。その理由 は、南岩本町にある建物の大半は1953（昭和28）年前後に建てられ
たため、南岩本町の地主は、土地区画整理事業から生じた開発利益 にも関わらず所有した土地に定住したと思われる。

北河原町の45筆地においてコリアンが所有した土地は、8筆地、 総面積 $358.60 \mathrm{~m}^{2}$ であり、8件、全てを日本人から所有権を取得し た。当時、北河原町には多数の工場が散在しており、工場で働いた コリアンによる所有権の変動が行われたが、その規模は少なかっ た。 $2 \mathrm{~m}^{2}$ 末満の土地、4件がコリアンに売買され、食材を栽培する畑 として利用されたことが特徴である。

南河原町の38筆地においてコリアンの所有であった土地は、15筆 地、総面積 $1819.67 \mathrm{~m}^{2}$ である。コリアンにかかわる土地所有の変化 は、日本人から7件、公共団体（大藏省、京都市）から2件である。 残り6件は、換地処分直後から土地の所有権を取得したコリアンが 土地を細分化し、それを再売買したケースである。南河原町におけ るコリアンの土地所有の特徴は、(1)前住所が北河原町であるコリア ンが小規模宅地を購入したこと、(2)コリアンが南川原町で所有した 総土地面積の 3 分の 1 をる大規模の土地を公共団体から購入したこ と、である。

河西町の74筆地においてコリアンが所有した土地は、4筆地、総 面積 $367.38 \mathrm{~m}^{2}$ 、全てが日本人から所有権を取得したケースであ る。

南松ノ木町の131筆地においてコリアンが所有した土地は、19筆 地、総面積 $1292.97 \mathrm{~m}^{2}$ である。コリアンにかかわる土地所有の変化 は、日本人から 14 件、法人から 1 件があり、残り 4 件は換地処分直後 からコリアンが土地の所有権を取得したケースである。北・南松， 木町の場合は、川沿い敷地の特性に従って染色業が盛んであり、南 松ノ木町には土地区画整理事業の以前から工場が多かった。工場の 尞、または近所の長屋に居住したコリアン労㗢者が多かったことに も関わらず、土地を購入した事例は少ない。

\section{7. まとめ}

東九条地区におけるコリアンの土地所有の特徴として、土地所有 変化のパターンと土地を収得する以前の住所を分析した結果、東九 条地区の土地のおよそ $46 \%$ が、東九条地区及びその周辺地区を前住 所地にしている人によって収得された。一方、土地を収得する前の 住所が他地域であるケースは約8\%に過ぎないことが明らかになっ た。さらに、公共団体ならびに法人企業から大規模土地を購入する ことに成功した者たちがいたことが挙げられる。彼らは、いったん 購入した土地を分筆（細分化）し、他のコリアン及び日本人に売買 した事実が明らかになった。このことは、大規模な土地を購入する ことができるほどの豊かな経済的力を持ったコリアンが存在したこ とを物語る一方で、在日コリアンの中にも経済的な階層分化が発生 していたことをも意味している。

旧都市計画法第13条認可による強制的な土地区画整理事業によっ てインフラストラクチャーが整備され、結果として、地価が上昇し た。地主たちは、上昇した地価から開発利益を得るために、買手を 選ばず土地を売買した。それが、在日コリアンたちが比較的容易に 土地所有を実現することができるきっかけとなった。土地を取得し たコリアンたちは、住宅を建築し、コリアン相手の借家経営などに も乗り出し、集住を加速化させた。

次稿では、この点についての詳細な分析結果を展開したい。 
謝辞

本研究を進めるあたりに、東九条まちづくりサポートセンターの 宇野豊氏、N P O法人京都コリアン生活センター「エルファ」のチ ヨンフィスン理事長ならびに職員の皆様のご協力をいただいた。

又、筑波大学の吉田友彦氏には貴重な助言やサポートをしていた だきました。ここに改めて謝意を表する。

\section{参考文献}

[1]池添昌幸、竹下輝和「旧法期土地区画整理事業における街区標準及び画 地標準と換地処分時の計画実態」、日本建築学会計画系論文集、第500号、 pp119-126、1997. 10

[2]池添昌幸、竹下辉和「旧法期土地区画整理事業の計画変更過程」、日本建 築学会計画系論文集，第516号、pp107-114、1999.02

[3] 金広烈「戦間期日本における定住朝鮮人の形成過程」、一橋大学大学院社 会学研究科地域社会研究専攻博士論文、1997. 11

[4]皇紀2600年奉祝京都市陶化学区記念事業達成会「陶化誌」、1940.12

[5]高晚鍾「大都市におけるエスニック・コミュニティの構造分析」、東京都 立大学大学院社会学研究課社会学専攻博士諭文、1998

[6]曹賢美「在日韓国・朝鮮人の集住地域の形成と実態」、㧍茶の水女子大学 人間文化研究科比較文化学専攻博士論文、1998

[7] 鶴田佳子、佐藤圭二「近代都市計画初期における京都市の市街地開発に 関する研究一1919年都市計画法第13条認可都市区画整理事業を中心として一 」、日本建築学会計画系論文集、第458号、1994.04

[8]Hong Raha Yi「在日韓国・朝鮮人一形成過程と現在そして彼らの役割一 $」$ 、在外韓人研究会（韓国）、2000.12

[9]吉田友彦「不良住宅地区の変容から見る住環境整備論に関する考察」、京 都大学三村研究室修士論文、1993.03

[10]吉田友彦「日本に都市における外国人マイノリティの定住環境確立課程 に関する研究」、京都大学大学院工学研究科博士論文、1996.10

\section{註}

1) 参考文献3

2) 参考文献9、10

3）昭和 25 年以降、税務署から法務局へ土地台帳 ・付属地図（いわゆる公図） が移管。この土地台帳は昭和 30 年代まで使用。その後、「旧土地台帳」とし て保存されている。

4）「在日本大韓民国民団」及び「在日本朝鮮人総連合会」

5）京都市が作成した「京都市基本計画」（2001）の南区の整備方針による。

6) 東九条地区整備に関する調查報告書による。

7) 参考文献4

8) 1914 （大正3）年の京都駅改築に伴うつけ変えによって廃川となった旧高瀬 川流路から須原通まで、北は八条通、南は旧九条通（現在の河原町通以東の 九条通南の一筋目）と、現在の西山王町、河西町の一部を含む広い地域であ った。

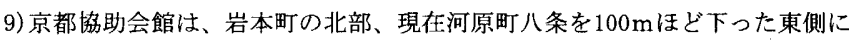
建設された。その理由は、当時、崇仁地区や岩本町で増えつつあったコリア ンの居住と関係があると考えられる。

10)参考文献8

11) 参考文献5

12）東九条地区には、街区公園2箇所、児童遊園が3筒所 あり、街区公園の公 園面積比率は4.5\%である。また誘致距離（250m）を見ると、次頁のようにな っている。また、地域東部に接する鴨川沿いにも緑道及び公園が整備されて いる。地区内においてまとまった緑地はおおむね記のような公園にしかな く、民有地の緑惊きわめて稀少である。

13）高瀬川：人工河川である高瀬川は1938（昭和13）年の土地区画整理事 業によって須原通に並行するように改修された。河道幅は約 $6 \mathrm{~m} 、$ 水深は約 $1.1 \mathrm{~m}$ で、都市河川の整備目標である降雨强度 $50 \mathrm{~mm} / \mathrm{h}$ に対応寸る基淮で建設さ た。常習浸水区域であった東九条地区は、鴨川からの取水制御と公共下水道 の整備が行われてから浸水が見られなくなった。

14）土地区画整理事業施行地区内の地権者から執行側が確保した土地で，その 売却収入は土地区画整理事業の財源の一部となる。

(2005年 6 月 10 日原稿受理， 2005 年 10 月 8 日採用決定 $)$ 